\title{
Floor Cleaning Agent
}

National Cancer Institute

\section{Source}

National Cancer Institute. Floor Cleaning Agent. NCI Thesaurus. Code C122493.

Any of the compounds used for floor polishing, waxing and stripping. Chemicals in these

products include diethylene glycol ethyl ether, aliphatic petroleum distillates and nonylphenol ethoxylate, ethanolamine, butoxyethanol, and sodium hydroxide. Exposure to these chemicals may cause headaches, dizziness, nausea, difficulty concentrating, fatigue, wheezing, coughing, asthma attacks, hypersensitivity pneumonitis, and eye, nose, throat, and skin irritation. 